\title{
115.Zur Verhütung des Operationsschocks bei der Radikaloperation des Rectumcarcinoms mit besonderer Berücksichtigung des synchronen Verfahrens
}

\author{
P. Fuchsig, H. LILL, E. Schima* und M. VoILL-Wien/Österreich
}
Prevention of Operative Shock in Radical Excision of Rectal Cancer
Especially Regarding the Synchronous Technique

Summary. In cases of rectal cancer, which can be removed only by combined excision, the synchronous procedure is the method of choice. The essential benefits of this operation are technical facilitation, mutual help in dissection, exact bleeding control in any situation and the removal of the tumour before closing the pelvic floor. There is no increased risk of shock as a result of two operations at the same time. Two pints of blood are sufficient in normal cases.

In the 1st Surgical University-Clinic in Vienna 210 synchronous combined excisions of the rectum were performed by 15 surgeons during the years 1966 to 1970. The resectability rate was $88 \%$ of all diagnosed cases and the operative letality was $6 \%$.

Zusammenfassung. Bei Rectumcareinomen, die nur mittels kombinierter Exstirpation entfernbar sind, ist das synchrone Vorgehen die Methode der Wahl. Technische Vereinfachung, gegenseitige Hilfe bei heikler Präparation, exakte sofortige Blutstillung auch an unübersichtlicher Stelle und die Entfernung des Präparates vor Schluß des Beckenbodens sind die Hauptvorzüge des Verfahrens. Ein erhöhtes Schockrisiko durch die zwei gleichzeitigen Akte besteht nicht. Zwei Blutkonserven genügen im Regelfall. In den Jahren 1966-1970 wurden an der I. Chirurgischen Universitätsklinik in Wien 210 synchrone Rectumexstirpationen von 15 Operateuren ausgeführt. Die Resektionsquote betrug $88 \%$ aller diagnostizierten Fälle bei einer Letalität von $6 \%$.

Das Manuskript der Zusammenfassung zu dem Vortrag 116, Ergebnisse der operativen Behandlung der Colon- und Rectumcarcinome aus den Jahren 1958-1970 von K. Th. Hofmann*, B. Täger, F. Eitel und W. Zimmermann-Homburg a. d. Saar wurde nicht vorgelegt.

\section{Ergebnisse bei einzeitigen Colonresektionen ohne entlastende Darmfistel}

H. BECKER * und E. UNGEHEUER-Frankfurt a. M.

\section{Results of One-Stage Colon Resections without Relieving Intestinal Fistula}

Summary. On the basis of our own clinical material which comprises 514 surgically treated carcinomas of the colon (radical operations in $58.5 \%$ ) and covers $71 / 4$ years, we again approach the problem of the one-stage operation without a relieving intestinal fistula. 194 one-stage resections of the transverse and left colon 